\title{
POLITICAL POLARIZATION, INCOME INEQUALITY AND SIZE OF GOVERNMENT
}

\author{
Sacit Hadi AKDEDE ${ }^{1}$
}

\author{
Nazlı KEYifLi²
}

\begin{abstract}
This paper empirically investigates the determinants of political polarization. Size of government and income distribution are the main independent variables along with other controlling variables. The statistical analysis uses panel data econometric. The sample of countries includes 57 countries and time period spans between 1990 and 2015. Results of regressions analysis indicates that increased income inequality increases political polarization. Political polarization is derived from World Values Survey (WVS). It is measured as standard deviation of responses to the question "what is role for government". In addition, results of our empirical indicates that increased government size reduces the political polarization. The paper explains the links for these findings. It concludes with some policy implications.
\end{abstract}

Keywords: Political Polarization, size of government, economics inequality

JEL Code: H50, P16, D31.

\section{Introduction}

In recent years, political polarization in economics and political Sciences has resulted in significant political consequences because of it can affect the political decision-making processes in governments and legislative bodies (Lindqvist \& Östling, 2010: 543; Campante \& Hojman, 2013: 91). For example, economic performance of political polarization, fiscal policy (Lindqvist \& Östling, 2010), legislative efficiency (Hacker, 2004), income inequality (McCarty vd., 2006; Meltzer \& Richard 1981) and economic development (Frye, 2002) is seen to have a significant impact. In addition, political polarization may depend on the development of economic outcomes in a society, as well as on the degree of discrimination in political issues (Grechyna, 2016: 10). Polarization is closely related to social and political unrest in many developed and developing countries (Montalvo \& Reynal-Querol, 2005: 301). Since the economic greatness of the state may be related to political polarization, the state can manage to minimize the friction in society by using fiscal policy tools (Lindqvist \& Östling, 2010: 543).

At the same time, political polarization has escalated to a higher level in fragmented governments or legislative bodies, in countries which poor, ethnically separated levels of trust are low, and income inequality is high (Lindqvist \& Östling, 2010; Grechyna, 2016). In countries which polarization is high, the budget deficit is slightly higher than in countries where polarization is low, and economic inequality is quite large (Alt \& Lassen, 2006: 541). Within the framework of these statements, it is believed that polarization (political and social) as a result of empirical research has a negative impact on government policies in general (Testa, 2012: 1104). Political polarization

\footnotetext{
1 Prof. Dr., Adnan Menderes University, Nazilli iiBF, shakdede@adu.edu.tr

2 Asst. Prof., Gümüşhane University, iiBF, n.keyifli@hotmail.com
} 
is linked to the existence of social unrest in general and to more conflicts in the political and social field (Estaban \& Ray, 2011: 1345), as well as to the fact that there is no accepted definition in the economic literature and polarization can also be seen as the formation of clusters or groups (Akdede, 2012: 21). In this research, income distribution and the impact of the economic size of government on political polarization were investigated by using a political polarization measure based on the political preferences of citizens based on their own declarations.

\section{Literature Review}

In the literature, there are a few empirical studies investigating the relationship between political polarization and income inequality and the economic size of government. The main reason for this is the difficulty of defining the value of political polarization in a statistically measurable way.

McCarty et al. (2003) investigated the relationship between income inequality and partisan policies using the probit regression method using the National Election Study (NES) data for the period 1952-2000. Concluded that inequality and polarization increased in parallel.

Lindqvist and Estring (2010) examined the relationship between political polarization and the size of government. In this research, they tried to explain the relationship between political polarization and the size of the state by taking advantage of the data of 74 countries from the 1995-2005 period. They have seen that the relationship between political polarization and the size of the state is strong in countries where democratic and the size of the state is small, but in countries where antidemocratic relations are not.

Akdede (2012) empirically examined the relationship between economic inequality and political polarization and political fractionalization for 17 European countries using data from the 1980s, $1990 \mathrm{~s}$ and 2000s. The rising inequality of income has been shown to increase the polarization of the political party and reduce the political fractionalization and the polarization of the political party has decreased by the per capita GDP.

\section{Data And Regression Results}

In this research, the effects of income distribution and the economic size of the government on political polarization were analyzed using the panel data method. The study included 5-year average data from 57 countries for 1990-2015. In this research, the data set was created for 5 years because the political polarization data was organized for 5 years. The data set and model of the study were first defined before the findings obtained in the analysis. The variables used in the model are presented in Table 1. 
Tablo 1. Data Set

\begin{tabular}{|c|c|c|c|}
\hline Variable Type & Variable Name & Abbreviation & Source \\
\hline Dependent Variable & Political Polarization & PP & World Values Survey \\
\hline \multirow{7}{*}{$\begin{array}{l}\text { Independent } \\
\text { Variable }\end{array}$} & Income Inequality (Gini) & GIN & \multirow{4}{*}{ World Bank } \\
\hline & Unemployment & UN & \\
\hline & GDP & GDP & \\
\hline & $\begin{array}{c}\text { Government Final } \\
\text { Consumption Expenditures }\end{array}$ & CE & \\
\hline & Religious Fractionalization & RF & $\begin{array}{c}\text { The Quality of Government } \\
\text { Dataset }\end{array}$ \\
\hline & $\begin{array}{c}\text { Government } \\
\text { Fractionalization }\end{array}$ & GF & \multirow{2}{*}{$\begin{array}{l}\text { World Bank's Database on } \\
\text { Political Institutions }\end{array}$} \\
\hline & Election System & ES & \\
\hline
\end{tabular}

Our dependent variable, which is the political polarization, is used as standard deviation. In the World Values Survey database, the measurement value calculated by the standard deviation of the survey question "government responsibility" was used (Lindqvist and Östling, 2010). The survey question "government responsibility" that we used in the study takes values measured in 1 to 10 scales. 1 "people must take more responsibility for themselves" means that they are fully involved. 10 "the government must take more responsibility for everyone," he said. Looking at the arguments used in the model; The Gini coefficient was used for income inequality and was obtained from the World Bank database. In the Gini index, 0 means perfect equality and 100 means perfect inequality. The variable of religious fractionalization in the model is derived from the "the Quality of Government Dataset" database. Gets values from 0 to 1.0 means that there is no religious fractionalization and 1 means that there is no religious fractionalization. Government fractionalization and pluralist selection system variables were obtained from the "The World Bank's Dataset on Political Institutions" database. In order to measure the economic size of government, another independent variable, the ratio of the government's final consumption expenditures to gross domestic product was taken into account and that variable was obtained from the World Bank database. Government fractionalization variable takes values from 0 to 1 . In terms of government fractionalization, for the most part, we see more than two parties in the government for a value greater than 0.5 , and as the number approaches 1 , the number increases. GDP per capita, unemployment rate variables we use in our study were obtained from the World Bank database. The panel data method, which enables to the use of time series and horizontal section together, provides more information about both periods and units (Tatoğlu, 2013: 3).

The model used in the study is primarily referred to in the study Akdede (2012) and the econometric model is as follows, taking into consideration the studies of Lindqvist \& Estling (2010);

$P P i t=\beta 0+\beta 1 G I N i t+\beta 2 U N i t+\beta 3 G D P i t+\beta 4 C E i t+\beta 5 R F i t+\beta 6 G F i t+\beta 7 E S i t+\varepsilon i t$ 
In order to obtain preliminary information, descriptive statistics have been looked. The descriptive statistics for the variables in the model are given in Table 2. During the analysis period (19902015), the average political polarization of countries was realized at 2.78 . The country with the highest political polarization is Mexico with a level of 3.6, while the country with the lowest political polarization is Pakistan with a level of 1.91. On the other hand, in the relevant period, while the lowest government consumption expenditure was in Nigeria at 1.14\%, Sweden was the country with the highest consumption expenditure of $26.4 \%$. Morocco $(0.003)$, Turkey $(0.004)$ and Algeria (0.009) are the first three countries to have the highest religious fractionalization, while South Africa (0.86), Australia (0.82) and the United States (0.82) are the first three countries to have the lowest religious fractionalization.

Tablo 2. Descriptive Statistics

\begin{tabular}{|l|l|l|l|l|l|}
\hline Variable Name & Observation & Mean & Std. Dev. & Min. & Max. \\
\hline Political Polarization & 162 & 2.78 & 0.36 & 1.92 & 3.6 \\
\hline Gini & 220 & 37.52 & 9.26 & 16.6 & 63.9 \\
\hline GDP & 281 & 10965.27 & 15839.8 & 154.70 & 94151.1 \\
\hline Unemployment & 285 & 9.05 & 6.56 & 0.38 & 35.8 \\
\hline Religious Fractionalization & 285 & 0.43 & 0.23 & 0.00 & 0.86 \\
\hline $\begin{array}{l}\text { Government Final } \\
\text { Consumption } \\
\text { Expenditures }\end{array}$ & 280 & 15.51 & 5.03 & 1.14 & 26.4 \\
\hline Election System & 278 & 0.61 & 0.17 & 0.05 & 1 \\
\hline $\begin{array}{l}\text { Government } \\
\text { Fractionalizaiton }\end{array}$ & 278 & 0.30 & 0.27 & 0 & 0.87 \\
\hline
\end{tabular}

Panel data results is presented in Table 3.

Tablo 3. Panel Data Results

\begin{tabular}{|l|l|l|}
\hline \multicolumn{3}{|l|}{ Dependent Variable: Political Polarization } \\
\hline Independent Variables & Coefficient & z- Statistics \\
\hline GIN & $0.0166476^{* * *}$ & 4.70 \\
\hline UN & -0.0016072 & -0.26 \\
\hline GDP & $-3.89 \mathrm{e}-06^{* *}$ & -2.24 \\
\hline CE & $-0.015214^{* *}$ & -1.99 \\
\hline RF & -0.1353446 & -1.27 \\
\hline GF & $0.169571^{*}$ & 1.72 \\
\hline ES & $-0.4250378^{*}$ & -1.89 \\
\hline Constant & $2.679892^{* * *}$ & 11.17 \\
\hline Number of Observations & & 127 \\
\hline $\boldsymbol{R}^{2}$ & \multicolumn{2}{|c|}{0.51} \\
\hline F Statistic & \multicolumn{2}{|c|}{$0.000^{* * *}$} \\
\hline Hausman Test & \multicolumn{2}{|c|}{0161} \\
\hline
\end{tabular}

Note: $* * *, * *, *$ respectively $\% 1, \% 5$ ve $\% 10$ indicate significance levels. 
According to the panel data, the model was statistically significant (F-test). According to the analysis results, there is a strong and positive relationship between income inequality and political polarization. GDP, government consumption expenditures, and political polarization between the electoral system are statistically significant and negative. There was a statistically significant and positive relationship between goverment fractionalization and political polarization. There is no statistically significant correlation between unemployment rate and religious diversity and political polarization.

\section{Conclusion}

In this research, the determinants of political polarization were empirically investigated by taking the 5-year average of the annual data of 57 countries for the 1990-2015 period. Analysis results show that the most powerful determinant of political polarization in a society is income inequality. Government consumption expenditures and per capita GDP are seen as other important factors that reduce political polarization in one country. On the other hand, cultural differences, such as religious fractionalization, are not as important as economic factors such as income inequality, per capita GDP and government consumption expenditure.

\section{References}

Akdede, S., H. (2012). Income Inequality and Political Polarization and Fracturalization: An Empirical Investigation of Some European Countries. Bulletin of Economic Research, 64 (1), 20-30.

Alt, J. E. \& Lassen, D. D. (2006). Transparency Political Polarization and Political Budget Cycles in OECD Countries. American Journal of Political Science, 50 (3), 530-550.

Campante, F. R. \& Hojman, D. A. (2013). Media and Polarization Evidence from the Introduction of Broadcast TV in the United States. Journal of Public Economics, 100, 79-92.

Esteban, J. \& Ray, D. (2011). Linking Conflict to Inequality and Polarization. American Economic Review,101 (4), 1345-1374.

Frye, T. (2002). The Perils of Polarization: Economic Performance in the Postcommunist World. World Politics, 54 (3), 308-337.

Grechyna, D. (2016). On the Determinants of Political Polarization. Economics Letters, 144, 10-14.

Hacker, J. S. (2004). Privatizing Risk Without Privatizing the Welfare State: the Hidden Politics of Social Policy Retrenchment in the United States. The American Political Science Review, 98 (2), 243-260.

Lindqvist, E., \& Östling, R. (2010). Political Polarization and the Size of Government. The American Political Science Review, 104 (3), 543-565.

McCarty, N., Poole, K. T. \& Rosenthal, H. (2006). Polarized America: The Dance of Ideology and Unequal Riches. MIT Press.

Meltzer, A. H., \& Richard, S. F. (1981). A Rational Theory of tha Size of Government. Journal of Political Economy, 89 (5), 914-927. 
Montalvo, J.G. \& Reynal-Querol, M. (2005). Ethnic Polarization, Potential Conflict, and Civil Wars. The American Economic Review, 95 (3), 796-816.

Tatoğlu, Y. F. (2013). Panel Veri Ekonometrisi: Stata Uygulamalı (Ikinci Baskı), İstanbul: Beta Yayınları.

Testa, C. (2012). Is Polarization Bad?. European Economic Review, 56 (6), 1104-1118. 